COMMUNITY NATURAL RESOURCE MANAGEMENT:

THE CASE OF WOODLOTS IN NORTHERN ETHIOPIA

Berhanu Gebremedhin, John Pender and Girmay Tesfaye

\author{
Environment and Production Technology Division \\ International Food Policy Research Institute \\ 2033 K Street, N.W. \\ Washington, D.C. 20006 U.S.A.
}

April 2000

EPTD Discussion Papers contain preliminary material and research results, and are circulated prior to a full peer review in order to stimulate discussion and critical comment. It is expected that most Discussion Papers will eventually be published in some other form, and that their content may also be revised. 


\begin{abstract}
This paper examines the nature of community management of woodlots and investigates the determinants of collective action and its effectiveness in managing woodlots, based on a survey of 100 villages in Tigray, northern Ethiopia. We find that collective management of woodlots generally functions well in Tigray. Despite limited current benefits received by community members, the woodlots contribute substantially to community wealth, increasing members' willingness to provide collective effort to manage the woodlots. We find that benefits are greater and problems less on woodlots managed at the village level than those managed at a higher municipality level, and that the average intensity of management is greater on village-managed woodlots. Nevertheless, we find little evidence of differences in collective management of woodlots or its effectiveness on village vs. municipality-managed woodlots, after controlling for other factors. The factors that do significantly affect collective action include population density (higher collective labor input and lower planting density at intermediate than at low or high density), market access (less labor input, planting density and tree survival where market access is better), and presence of external organizations promoting the woodlot (reduces local effort to protect the woodlot and tree survival). The finding of an inverse U-shaped relationship between population density and collective labor input is consistent with induced innovation theory, with the increased labor/land ratio promoting collective effort to invest in resources as population density grows to a moderate level, while incentive problems may undermine collective action at high levels of population density. The negative effect of market access suggests that higher opportunity costs of labor and/or increased "exit options" undermine collective resource management. The negative effect of external organizational presence suggests that external organizations are displacing local efforts to protect woodlots. These findings suggest collective action may be more beneficial and more effective when managed at a more local level, when the role of external organizations is more demand-driven, and when promoted in intermediate population density communities more remote from markets. In higher population density settings and areas closer to markets, private-oriented approaches are likely to be more effective.
\end{abstract}




\section{CONTENTS}

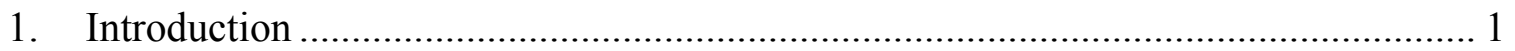

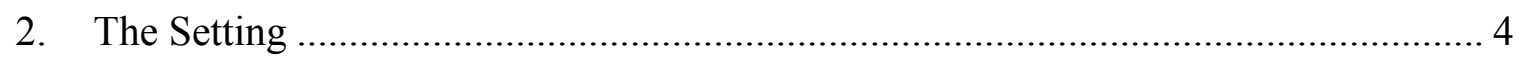

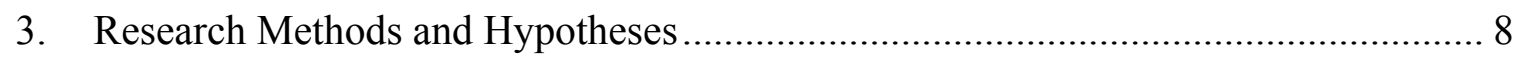

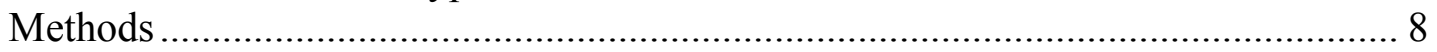

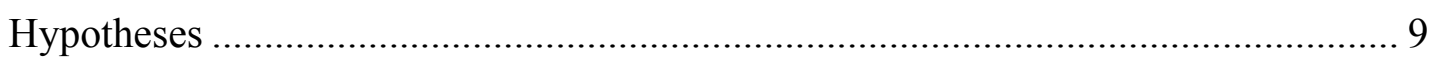

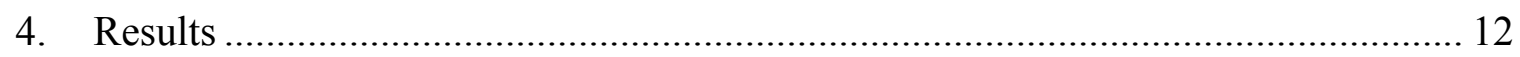

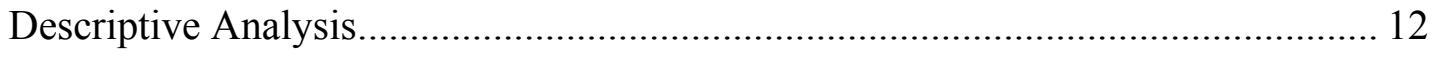

Econometric Analysis....................................................................................... 18

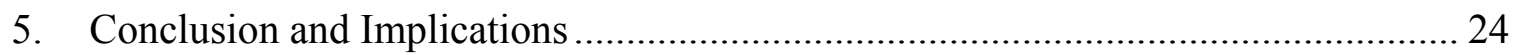

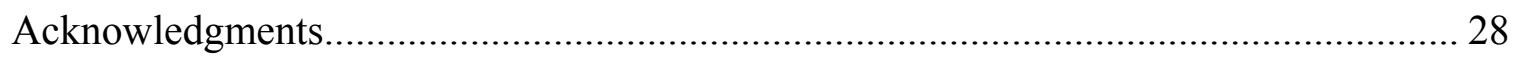

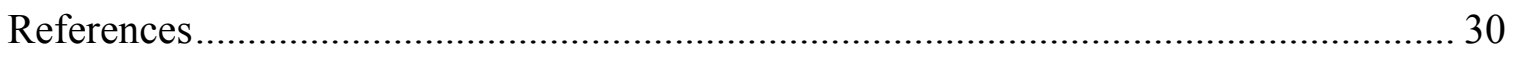




\title{
COMMUNITY NATURAL RESOURCE MANAGEMENT: THE CASE OF WOODLOTS IN NORTHERN ETHIOPIA
}

\author{
Berhanu Gebremedhin ${ }^{*}$, John Pender ${ }^{* *}$ and Girmay Tesfaye ${ }^{* * *}$
}

\section{INTRODUCTION}

Common property resources ${ }^{1}$ are important sources of timber, fuelwood, and grazing land in developing countries. Under unrestricted access by community members, or ineffective use regulations, these resources are exploited on a first-come, first-served basis. Each individual user of the resource will tend to continue to utilize the resource until her average revenue is equal to the marginal cost of utilizing the resource (Gordon, 1954). This results in overexploitation of the resource and the scarcity rent of the resource becomes dissipated.

The solution to the problem of resource degradation in developing countries depends not only on appropriate technologies and efficient market prices, but also on local level institutions of resource management and the organizations to enforce them (Baland and Platteau, 1996; Rasmussen and Meinzen-Dick, 1995). Community resource management institutions and organizations are now receiving greater attention as a viable

\footnotetext{
* Postdoctoral Scientist, International Livestock Research Institute, Addis Ababa.

${ }^{* *}$ Research Fellow, International Food Policy Research Institute, Washington, D.C.

*** Professor of Economics, Mekelle University College, Mekelle, Ethiopia.

${ }^{1}$ Common property resources are defined as those resources that are owned and managed by a given community. They are contrasted with open access resources, which have no defined owner.
} 
alternative to regulation by the state or privatization as a means of rectifying inefficiencies caused by attenuated property right systems, externalities, and other market failures.

However, devolving rights to local communities to help build institutions for common property management may not be a sufficient condition for sustainable use of such resources. Effectiveness in internal governance is needed for the effective application of community rules (Swallow and Bromley, 1995; Turner et al., 1994). Hence, the need to identify factors that facilitate or hinder the development and effectiveness of local organizations becomes important.

In Ethiopia, rural communities depend primarily on common property resources for irrigation water, construction material, fuelwood and grazing land. Population pressure, market and government failures, and the absence or ineffectiveness of use regulations of common property resources has resulted in severe degradation of the resources. Perhaps as a result, Ethiopia has been identified as the country with the most environmental problems in the Sahel belt (Hurni, 1985).

Resource degradation is particularly severe in the northern region of Tigray. Soil erosion, soil nutrient depletion, moisture stress, deforestation and overgrazing are major environmental problems in the region (Fitsum Hagos, et al. 1999). Currently forests and woodlots cover less than $2 \%$ of the regional area (BoANRD, 1995). The region depends almost entirely on imported construction material. Severe shortage of fuelwood has rendered rural communities increasingly dependent on animal dung for fuel, contributing to the problem of declining soil fertility (Fitsum Hagos, et al. 1999; Berhanu Gebremedhin, 1998). Despite the fact that about $40 \%$ of the total land area is used for grazing (BoANRD, 1995), shortage of feed sources is the major livestock production problem. 
The Tigray region is known not only for severe resource degradation, but also for concerted efforts to redress the problem, especially since 1991. Major strategies of environmental rehabilitation include construction of stone terraces, soil bunds, and micro dams; establishment of area enclosures (areas enclosed from human and animal interference to promote natural regeneration) and community woodlots (enclosures with enrichment plantation of trees or areas of new plantation); and enforcement of grazing restrictions (Berhanu Gebremedhin, 1998). Since 1991, the role of local communities in resource management has been increasing, particularly in the management of area enclosures, woodlots and grazing lands. However, little evidence exists regarding the nature of local level institutions and organization for resource management in Tigray, or their effectiveness. More generally, there is still a paucity of such evidence for developing countries, despite increased attention in the literature to issues of common property resource management in recent years.

This paper seeks to address this lack of evidence on management of common property resources in developing countries. The paper has two inter-related objectives. First, it evaluates the nature and impact of community management in the regeneration of woodlots in Tigray, considering the benefits to communities from these areas and problems encountered. Second, it investigates using econometric methods the determinants of collective action and its effectiveness in managing community woodlots. 


\section{THE SETTING}

The study area, Tigray, is found in northern Ethiopia on the Sudano-Sahelian drylands zone (Warren and Khogali, 1992). It covers an approximate area of 80,000 sq. km, with a population of more than 3.3 million and annual population growth rate of $3 \%$. The topography of the region is characterized as mountainous plateau and the climate as tropical semi-arid (Virgo and Munro, 1978). Annual rainfall ranges from 450 to $980 \mathrm{~mm}$ with significant spatial and temporal variability (Berhanu Gebremedhin, 1998). Most of the precipitation falls within the three months of June, July and August, and with high intensity.

Agriculture is the mainstay of the economy of Tigray. More than $85 \%$ of the regional population depends on rainfed mixed crop-livestock subsistence agriculture, with oxen power supplying the only draft power for plowing. Except for some areas in the Western and Southern zones of the region which produce surplus during good rainfall years, the rest either produce just enough for subsistence during good rainfall years or face chronic food deficit. The causes of the structural food deficit include severe environmental degradation, low soil fertility, inadequate and erratic rainfall, vulnerability to pests, lack of appropriate technology, small size and fragmentation of land holding, lack of diversification in economic activities, lack of oxen for draft power and little use of modern inputs.

About $40 \%$ of the total area of the region is used for grazing (BoANRD, 1995). Most of the crop residue is used as feed, fuel or construction material. Several areas of the highland plateau of Tigray are said to have been covered with forests at the turn of the century (Wolde-Giorgis, 1993). Currently forests and woodlots cover only about $1.6 \%$ of the Area of Tigray (BoANRD, 1995). Cutting trees for fuel, timber, and agricultural 
implements, and clearing forests to expand agricultural land have exhausted the forest cover of the area. Forests, woodlots and grazing lands have been predominantly common property resources or open access resources in the region.

Since 1991, the Ethiopian government has embarked on an economic development strategy known as Agricultural Development-Led Industrialization (ADLI), which places greater emphasis on agricultural development. Within the framework of the ADLI, regional administrations have been able to draw economic strategies specific to their conditions. Conservation-based ADLI became the primary goal of economic development in Tigray, which focuses on conservation of natural resources and popular participation. The natural resource conservation and development effort in the region has been aimed at improving the management of soil and water resources, environmental rehabilitation and protection through area enclosures and development of community woodlots, the development of irrigation through the construction of micro dams and river diversions, and reforestation. Other elements in the regional ADLI include improving productivity in agriculture through improved agricultural practices and inputs, promoting off-farm employment through diversification of the rural economy, and development of rural infrastructure.

The experience with area enclosures and community woodlots in Ethiopia during the previous military government was disappointing. Within five years after the 1985 famine, more than 80,000 ha of hillsides were closed to most forms of use to foster the regeneration of indigenous plant species. By 1995, most of the enclosures and community woodlots were harvested or destroyed (Hoben, 1995). The factors responsible for the poor performance of the environmental reclamation program include inadequate scientific and technical knowledge, a standardized approach with out regard to local agro- 
ecological conditions, and disregard of the views and interests of the rural population whom the program was intended to serve. Program implementation was top-down, authoritarian and politicized.

Since 1991, area enclosures and community woodlots in Tigray have been developed through a more participatory process. A development agent of the Bureau of Agriculture and Natural Resource Development (BoANRD), in collaboration with the local tabia baito (local administration council), identify an area to be closed and/or planted. The final decision is then made at a general meeting of the community members. Site preparation for community plantation including construction of microbasins, terraces, and digging holes usually begins in late April of each year. Between 1992 and 1996, about 49 million seedlings are reported to have been planted in community woodlots (BoANRD, 1996). The average survival rate is reported to have been around $40 \%$, but can be as low as $10 \%$ in the lowland areas.

Guards who protect area enclosures or community woodlots are nominated from the local people and the community is expected to contribute for the payment of the guards. In areas where community contributions for guard payment are not forthcoming, site guards are either allowed to cut grass from the enclosure for private use or graze animals. In some cases, government or non-government organizations pay for the guard based on food-for-work programs.

The area enclosures and community woodlots were established primarily for ecological regeneration rather than economic benefits. However, people's expectations about economic benefits from these areas are increasing, which will present a major 
management challenge in terms of technical inputs and institutional arrangements for utilization and distribution of benefits.

The development of community woodlots requires tree seedlings. Three types of tree nurseries operate in Tigray: state, community and private (BoANRD, 1996). Until 1996, about 210 state nurseries with an average land area of half a hectare and a potential to produce more than 390,000 seedlings per year at full capacity had been operating in the region. State nurseries now sell seedlings to farmers. Community nurseries were launched in order to decentralize seedling distribution and reduce problems in seedling transportation. By 1996, about 446 community nurseries were operational with an average area of 0.04 ha and capacity of 60,000 to 80,000 seedlings per year. Community nurseries receive material and technical support from the BoANRD while the local community contributes labor and management. In addition to state and community nurseries, individual farmers raise their own seedlings, although on a limited scale.

Low survival rates and poor tree establishment in community woodlots appear to have encouraged a different tree planting arrangement in the region. Distribution of degraded communal lands, mostly gullies, for private tree plantation is now being practiced in the region. The initiative began in a village known as Echmare in Gulomekeda woreda (district) of the Eastern zone of Tigray in 1992 (BoANRD, 1996). The community, upon observation of the benefits of private tree plantation, divided communal land, in parcels of $3 \mathrm{~m}$ by $6 \mathrm{~m}$, to individuals for tree plantation. This initiative later was accepted at the regional level and distribution of communal land for private tree plantation is now occurring in several woredas of the region. 
There appears to be ambiguity in tree tenure rights in Tigray. Although a farmer has the ownership right to trees grown on his homestead and cultivated lands, he or she needs to get permission from the local baito to cut the trees. Regional laws also prohibit planting eucalyptus and cactus trees on cultivated land. The regional effort to plant trees has not been accompanied by proper incentives to encourage tree plantation by households or the community at large.

\section{RESEARCH METHODS AND HYPOTHESES}

\section{METHODS}

This study is based on a survey of 50 tabias (the lowest administrative unit in Tigray, comprising usually four or five villages) in the highlands ${ }^{2}$ of Tigray in the 199899 cropping season. Sample tabias were selected based on random sampling stratified by proximity to a market town and presence of an irrigation project. Within each tabia, two villages were selected randomly. A semi-structured questionnaire was administered with representative individuals at both levels. Each interview involved ten respondents chosen to represent different age groups, villages, primary occupations and gender. The survey collected information about changes in agricultural and natural resource conditions between 1991 and 1998, and their causes and effects.

Analysis of descriptive information from the survey was used to identify the nature of management of woodlots, the roles of different organizations (local and

\footnotetext{
${ }^{2}$ Highlands are defined as those areas above 1500 m.a.s.1..
} 
external) in managing them, and the benefits and problems encountered. Econometric analysis was used to investigate the determinants of collective action and its effectiveness in managing woodlots. The indicators of collective action and effectiveness used in the econometric analysis include the amount of uncompensated collective labor per capita invested in managing the woodlot, whether the community pays for a guard to protect the woodlot, whether there were any violations of the restrictions on use of the woodlot, the number of trees planted per hectare on the woodlot since its establishment, and the survival rate of the trees planted.

The type of regression model used depends on the nature of the dependent variable. We use a tobit model to explain collective labor investment and survival rate, since these variables are left-censored at zero. We use binary probit models to explain whether the community pays for the guard or whether there were violations of restrictions, since these are binary variables. We use least squares regressions for tree planting density, since this variable is not censored. In all regressions, coefficients and standard errors were corrected for the sampling weights and stratification, and the standard errors are robust to heteroskedasticity and non-independence of multiple observations from the same primary sampling unit (tabia).

\section{HYPOTHESES}

The factors used to explain variations in collective action and its effectiveness included population density, access to market, agricultural potential, the presence of external organizations, whether the woodlot is managed at the village or tabia level, and the area of the woodlot. Our hypotheses about how these factors may influence 
collective action draw from the literature on induced institutional innovation and collective action in managing common property resources (Boserup, 1965; Hayami and Ruttan, 1985; North, 1990; Olson, 1965; Rasmussen and Meinzen-Dick, 1995; Baland and Platteau, 1996; Pender and Scherr, 1999; Pender, 1999; Otsuka and Place, 1999). At low levels of population density, the demand for collective action to manage resources will be low, and the organizational costs of attaining it high. As population density grows, increasing land scarcity will increase the benefits of improved resource management, whether through collective action or development of private property. This may induce increased collective action, particularly if economies of scale or high exclusion costs favor collective over private management. However, as population density grows to very high levels, the gains from collective action may be outweighed by the incentive problems associated with it, as rising scarcity increases the benefits from attempting to "free-ride" on the efforts of others. The economies of scale of collective action may diminish, or be replaced by diseconomies of scale at higher population density. As a result, the net benefits of collective action may stabilize or even decline while the net benefits of privatization continue to increase with increasing population density. Thus, there may be an "inverse U relation" between collective action and population density, with higher levels and effectiveness of collective action at intermediate population density than at very low or very high density (Pender, 1999).

Access to markets may also have mixed effects on collective action. On one hand, having better access to markets increases the value of resources and thus the value of managing resources well, which may favor collective action. On the other hand, better market access may tend to undermine individuals' incentives to cooperate by increasing the 
opportunity cost of labor or by offering more "exit" options, making it more difficult to punish those who fail to cooperate (Baland and Platteau, 1996; Pender and Scherr, 1999). Thus, the impact of market access on collective action can only be determined empirically. Agricultural potential may have mixed impacts on collective action for similar reasons.

The presence of external organizations may favor collective action when those organizations are seeking to provide complementary inputs to local collective inputs, but may undermine collective action if external organizations are providing substitutes for collective action, or otherwise undermining collective action (such as by increasing the "exit options" of local community members, as noted above) (Pender and Scherr, 1999).

We expect that collective action is easier to obtain and likely to be more effective when cooperation of a smaller number of people is needed, when the beneficiaries are a more homogenous and stable group, and when the benefits received by those people are more apparent (Olson, 1965; Rasmussen and Meinzen-Dick, 1995; Baland and Platteau, 1996). Thus, we expect that collective action will be more prevalent and more effective for village-managed woodlots than for tabia-managed woodlots, since villages are smaller, more cohesive and a more stable unit than tabias (e.g., the tabias were reorganized in 1995 to include more villages) and since, as noted below, the benefits accruing to community members from village-managed woodlots have been greater than the benefits from tabia-managed woodlots.

To the extent that economies of scale are important in favoring collective action (for example, in protecting the woodlot), we expect that collective action should be greater and more effective on larger woodlots. 


\section{RESULTS}

\section{DESCRIPTIVE ANALYSIS}

Almost nine out of ten tabias in the highlands of Tigray have woodlots (Table 1).

There are nine woodlots per tabia on average, and these average about 8 ha. in size, although there is much variation in numbers and sizes of woodlots across communities.

\section{Table 1: Characteristics of community woodlots}

Means (standard errors in parentheses) ${ }^{\mathrm{a}}$

\begin{tabular}{lccc}
\hline Item & Village- & Tabia-managed & \\
managed & 57.7 & 29.9 & All woodlots \\
\hline Percentage of tabias with a woodlot & $(8.1)$ & $(7.2)$ & 87.6 \\
& & & $(5.8)$ \\
Number of woodlots per tabia & 7.2 & 0.9 & 9.0 \\
& $(1.3)$ & $(0.2)$ & $(1.3)$ \\
Area of woodlots (ha) & & & \\
& $(0.1$ & 18.5 & 7.9 \\
Percentage of woodlots established since & & $(3.8)$ & $(1.4)$ \\
1991 & 75.6 & & \\
& $(8.8)$ & 91.3 & 78.0 \\
Percentage of woodlots promoted by & & $(5.2)$ & $(7.6)$ \\
a program or organization & 94.6 & 98.7 & 95.5 \\
- promoted by BoANRD & $(3.8)$ & $(1.4)$ & $(3.0)$ \\
& 76.5 & 91.4 & 79.5 \\
- promoted by REST & $(8.7)$ & $(7.4)$ & $(7.2)$ \\
& 4.6 & 0.0 & 3.7 \\
- promoted by BoANRD and REST & $(3.7)$ & $(0.0)$ & $(3.0)$ \\
& 4.8 & 7.3 & 5.3 \\
- promoted by World Vision & $(4.6)$ & $(7.2)$ & $(3.9)$ \\
Percentage of woodlots where users are: & 4.8 & 0.0 & 3.8 \\
- All tabia members & $(4.6)$ & $(0.0)$ & $(3.7)$ \\
- Only village members & 0.0 & 94.8 & 19.6 \\
- Only the guard & $(0.0)$ & $(5.3)$ & $(6.4)$ \\
& 100.0 & 0.0 & 79.1 \\
& $(0.0)$ & $(0.0)$ & $(6.4)$ \\
a & 0.0 & 5.2 & 1.1 \\
& $(0.0)$ & $(5.3)$ & $(1.1)$ \\
\hline
\end{tabular}

\footnotetext{
${ }^{\mathrm{a}}$ Means and standard errors are corrected for sampling stratification and weights.
} 
Most of the woodlots have been established since the fall of the former Derg government in 1991. The establishment of most woodlots has been promoted by external organizations; usually the Tigray Regional Bureau of Agriculture and Natural Resource Development (BoANRD). In a few cases, non-government organizations, including the Relief Society of Tigray (REST) or World Vision, were involved.

Most woodlots are managed at the village level by the village council, and are used only by members of that village. However, about one third of the tabias that have woodlots manage them at the tabia level, in which case the tabia council is responsible for management. In almost all cases, all members of the tabia are allowed to use the tabia-managed woodlots, though in a few cases, only the guard is allowed to use the woodlot. Tabia-managed woodlots tend to be larger than village-managed ones, averaging more than 18 ha. in size compared to about 5 ha. for village woodlots.

The most common use allowed on woodlots is to cut and collect grass for animal feed, roof materials or other purposes (Table 2). Collecting fruits and beekeeping in woodlots are also commonly allowed. These uses are more common on village-managed than tabia-managed woodlots. Most other uses, including cutting trees, shrubs, branches, or roots; and collecting fuelwood, bark, leaves, or dung; are not allowed in woodlots. In a few cases, animals are allowed to graze in the woodlot, but only during a drought.

Woodlots are protected in almost all cases by a guard paid in cash or in kind. In some cases, the guard is compensated by being allowed to collect grass from the woodlot. For village-managed woodlots, the village residents pay the guard in most cases; while for tabia-managed woodlots, external organizations such as BoANRD and REST are 
Table 2: Allowed uses of community woodlots

Percentage of woodlots (standard errors in parentheses) ${ }^{a}$

\begin{tabular}{lccc}
\hline Use & Village- & Tabia- & \\
managed & managed & All woodlots \\
\hline Grazing & 0.6 & 8.9 & 2.3 \\
Cut and remove grass & $(0.6)$ & $(5.7)$ & $(1.3)$ \\
Collect fuelwood & 71.1 & 39.9 & 64.7 \\
& $(9.5)$ & $(15.0)$ & $(8.3)$ \\
Collect dung & 4.4 & 0.0 & 3.5 \\
& $(3.9)$ & $(0.0)$ & $(3.1)$ \\
Cut and remove trees or branches & 1.0 & 0.0 & 0.8 \\
& $(1.0)$ & $(0.0)$ & $(0.8)$ \\
Cut and remove shrubs & 0.0 & 0.0 & 0.0 \\
Collect leaves & $(0.0)$ & $(0.0)$ & $(0.0)$ \\
Collect bark & 0.0 & 0.0 & 0.0 \\
& $(0.0)$ & $(0.0)$ & $(0.0)$ \\
Collect roots & 0.0 & 0.0 & 0.0 \\
Collect fruits or seeds & $(0.0)$ & $(0.0)$ & $(0.0)$ \\
Beekeeping & 0.0 & 0.0 & 0.0 \\
& $(0.0)$ & $(0.0)$ & $(0.0)$ \\
& 0.0 & 0.0 & 0.0 \\
& $(0.0)$ & $(0.0)$ & $(0.0)$ \\
& 60.0 & 49.1 & 57.8 \\
& $(9.4)$ & $(15.4)$ & $(8.4)$ \\
& 61.1 & 38.4 & 56.4 \\
& $(9.6)$ & $(14.2)$ & $(8.4)$
\end{tabular}

${ }^{\mathrm{a}}$ Means and standard errors are corrected for sampling stratification and weights

more involved. Thus, it is more common for the local community to hire the guard for village-managed than for tabia-managed woodlots (Table 3).

Violations of restrictions are usually punished by a cash fine set by the community council, though in many cases fines are decided by the local court. The most common violations of restrictions in 1998 were cutting grass, grazing animals, and cutting trees or branches. Violations are more common on tabia-managed woodlots. Fines were typically less than 100 EB (about \$14 in 1998) for cutting grass or grazing, 
Table 3: Indicators of collective action to manage woodlots

\begin{tabular}{|c|c|c|c|}
\hline Indicator & $\begin{array}{l}\text { Village- } \\
\text { managed }\end{array}$ & $\begin{array}{c}\text { Tabia- } \\
\text { managed }\end{array}$ & $\begin{array}{c}\text { All } \\
\text { woodlots }\end{array}$ \\
\hline $\begin{array}{l}\text { Number of labor days per capita } \\
\text { invested in the woodlot in } 1998\end{array}$ & $\begin{array}{c}0.180 \\
(0.058)\end{array}$ & $\begin{array}{c}0.132 \\
(0.046)\end{array}$ & $\begin{array}{c}0.165 \\
(0.045)\end{array}$ \\
\hline $\begin{array}{l}\text { Percentage of woodlots protected by a } \\
\text { guard hired by the community }\end{array}$ & $\begin{array}{c}54.4 \\
(10.9)\end{array}$ & $\begin{array}{c}28.2 \\
(10.3)\end{array}$ & $\begin{array}{l}49.0 \\
(9.2)\end{array}$ \\
\hline $\begin{array}{l}\text { Percentage of woodlots where violations } \\
\text { of restrictions occurred in } 1998\end{array}$ & $\begin{array}{l}19.5 \\
(5.8)\end{array}$ & $\begin{array}{c}35.8 \\
(12.0)\end{array}$ & $\begin{array}{l}22.8 \\
(5.4)\end{array}$ \\
\hline Density of trees planted per ha. & $\begin{array}{c}5205 \\
(2372)\end{array}$ & $\begin{array}{l}1814 \\
(511)\end{array}$ & $\begin{array}{r}4453 \\
(1837)\end{array}$ \\
\hline Percentage survival rate of trees & $\begin{array}{l}61.6 \\
(5.8)\end{array}$ & $\begin{array}{l}71.1 \\
(9.6)\end{array}$ & $\begin{array}{l}63.7 \\
(5.1)\end{array}$ \\
\hline
\end{tabular}

${ }^{\mathrm{a}}$ Means and standard errors are corrected for sampling stratification and weights.

but could be much higher for cutting trees. In some cases a fine of as much as $500 \mathrm{~EB}$ and imprisonment were imposed for cutting trees.

Given the limited allowed uses of the woodlots, the benefits received are, not surprisingly, small. Of 164 village-managed woodlots in our sample, benefits were reported being received in 1998 from only 57 woodlots, mainly from cutting grass. Fewer than half of the households in the villages benefited from grass cutting on average, and the average estimated value of benefit was 2,783 EB per woodlot in 1998, only about $2 \mathrm{~EB}$ per capita in the villages where benefits were received. The benefits from tabia-managed woodlots are even lower, averaging only 352 EB per woodlot, less than 0.10 EB per capita.

Both local and external organizations play important roles in managing the woodlots. The most important local organization is the tabia or village council, 
depending on which level manages the woodlot. These organizations are involved in organizing and encouraging participation in woodlot development, developing rules and regulations, and financing the guard. The most important external organization is the BoANRD, which is involved mainly in providing material support (including seedlings) and technical assistance.

Villages are pursuing a more intensive strategy of woodlot management than tabias. Labor for tree planting, constructing soil and water conservation structures, weeding and harrowing is the main collective input, averaging 0.18 person-days per capita for village-managed woodlots and 0.13 person-days per capita for tabia-managed woodlots. Village woodlots are also planted much more densely than tabia woodlots. The average survival rate is somewhat higher for tabia woodlots, but considering the differences in planting densities, the number of surviving trees per hectare is still much higher on village woodlots. Considering the average returns per capita reported above, the average return per person-day invested in 1998 was about 10 EB for village-managed woodlots (comparable to the daily wage rate in rural Tigray), but less than 1 EB for tabia-managed woodlots.

Of course, the main benefit of a woodlot is not the value of grass collected, but the value of the trees in the woodlot, a non-liquidated capital gain. The most commonly planted trees in community woodlots are eucalyptus trees (especially globulos and camaldulensis). The average price of eucalyptus poles in the highlands of Tigray was about 28 EB per pole in 1998 (Jagger and Pender, 2000). Considering the average planting density (about 4500 trees per ha.) and survival rate (64 percent) reported in Table 3, a woodlot of average-sized eucalyptus trees would be worth more than 80,000 
EB per ha. on average, and much more in places where wood is very scarce. With an average of more than 70 ha. of woodlots per tabia ( 9 woodlots averaging almost 8 ha. each), this represents a substantial contribution to the wealth of communities in Tigray (averaging more than 5 million EB per community).

Thus, despite the limited amount of current benefits that people are receiving from community woodlots in Tigray, community members are generally satisfied that they will benefit from them eventually. Only a small fraction of communities report uncertainty about future benefits as a problem, though the problem is more commonly reported for tabia-managed than village-managed woodlots. The survey also inquired about other possible problems caused by woodlots, including reduction in grazing area, less wood available, pests, conflicts over use, and fire hazards. Most of these problems were generally regarded as minor or non-existent. In some communities, however, less grazing area, less availability of wood, and pests were seen as a major problem. In almost all cases, community members reported that the condition of the area where the woodlot was established had improved substantially as a result of the protection and investment in developing the woodlot.

Scarcity of fuelwood is a critical problem in many communities, mainly due to the deforestation that has occurred over many years. In the recent past, however, this scarcity may have been aggravated by restrictions on collecting fuelwood from woodlots. For example, 13 of the 100 sample villages reported that fuelwood had declined in rank as a source of fuel for cooking since 1991 (none reported an increase in importance of fuelwood), and in all of these cases, shortage of fuelwood was cited as the reason for the change. In 11 of these cases, the rank of dung as a fuel source had increased and, in 
several burning of crop residues had increased in importance (the rank of these sources did not change in other villages). Thus, even though restrictions on using woodlots are leading to improved conditions of the woodlots, they may be contributing to declining soil fertility in the near term as dung and crop residues are increasingly used for fuel, rather than being recycled to the soil.

To summarize the descriptive analysis, we find that woodlots are contributing substantially to the wealth of communities in Tigray, even though the near term benefits are limited due to restrictions on use. We find that village-managed woodlots are more common and smaller than tabia-managed woodlots, provide more near-term benefits, community members invest more effort in managing them, there are fewer violations of restrictions in the village woodlots, they are planted much more densely, and the number of surviving trees per hectare is also higher, despite somewhat lower survival rates per tree planted in village woodlots. In the next section, we test whether there are statistically significant differences in the management and survival of trees on village vs. tabia woodlots, controlling for other factors, as well as the other hypotheses presented earlier about factors affecting woodlot management.

\section{ECONOMETRIC ANALYSIS}

The initial econometric results are presented in Table 4. We include dummy variables for the different zones of Tigray to proxy for differences in agro-climatic potential (the Southern and Western zones have generally higher potential, due to better soils and irrigation in the Southern Zone and higher rainfall in the Western Zone), as well as other differences between these zones (e.g., differences in enforcement of restrictions 
Table 4: Determinants of collective action and its effectiveness on community woodlots, $1998^{\mathrm{a}}$

\begin{tabular}{|c|c|c|c|c|c|}
\hline Explanatory variable & $\begin{array}{l}\text { Collective labor input } \\
\text { (person-days per capita) }\end{array}$ & $\begin{array}{c}\text { Whether community } \\
\text { pays for guard }\end{array}$ & $\begin{array}{l}\text { Whether any violations } \\
\text { of restrictions occurred }\end{array}$ & $\begin{array}{l}\text { Number of trees } \\
\text { planted per hectare }\end{array}$ & $\begin{array}{c}\text { Survival rate of } \\
\text { planted trees }(\%)\end{array}$ \\
\hline $\begin{array}{l}\text { Central zone (cf. Southern } \\
\text { zone) }\end{array}$ & $-1.368 * * *$ & $-1.258 *$ & -0.437 & $-11374 * *$ & $18.03 * *$ \\
\hline $\begin{array}{l}\text { Eastern zone (cf. Southern } \\
\text { zone) }\end{array}$ & $-0.685 * *$ & $1.060 *$ & $-1.509 * * *$ & 2288 & $17.50 * *$ \\
\hline $\begin{array}{l}\text { Western zone (cf. Southern } \\
\text { zone) }\end{array}$ & -0.744 & 0.363 & -1.029 & 6853 & 5.24 \\
\hline $\begin{array}{l}1994 \text { population density (per } \\
\mathrm{km}^{2} \text { ) }\end{array}$ & $0.0288 * *$ & 0.0110 & -0.0122 & $-249.3 * *$ & 0.0085 \\
\hline 1994 pop. density squared & $-0.0000753 * *$ & -0.0000601 & 0.0000387 & $0.693 * *$ & -0.000255 \\
\hline $\begin{array}{l}\text { Distance to woreda town } \\
(\mathrm{km} .)\end{array}$ & $0.00653 *$ & -0.00462 & -0.00623 & $241.5 * *$ & $0.350 * * *$ \\
\hline $\begin{array}{l}\text { Woodlot promoted by } \\
\text { external organization }\end{array}$ & 0.611 & $-1.286^{* * *}$ & 0.0870 & 5505 & $-5.573 * * *$ \\
\hline $\begin{array}{l}\text { Woodlot managed by village } \\
\text { (cf. managed by tabia) }\end{array}$ & -0.136 & 0.668 & -0.158 & 5114 & 7.712 \\
\hline Area of woodlot (ha.) & 0.00239 & -0.0122 & 0.00500 & -278.3 & 0.426 \\
\hline Intercept & $-2.823 * *$ & 0.842 & 0.900 & 12067 & $38.95 * *$ \\
\hline Type of regression & Tobit & Probit & Probit & Least squares & Tobit \\
\hline $\mathrm{R}^{2}$ (if applicable) & NA & NA & NA & 0.525 & $0.436^{\mathrm{c}}$ \\
\hline $\begin{array}{l}\text { Number of positive } \\
\text { observations/total obs. }\end{array}$ & $66 / 223$ & $110 / 219$ & $53 / 219$ & $76 / 76^{\mathrm{d}}$ & $73 / 76^{\mathrm{d}}$ \\
\hline
\end{tabular}


on woodlots by zonal and woreda authorities). We include population density and population density squared to test for an inverted-U shaped relationship between population density and collective action. Market access is represented by distance to the woreda (district) town, which is usually where farmers market their produce and purchase inputs. The effect of external organizational presence is investigated by including a dummy variable indicating whether the woodlot was promoted by an external organization. Another dummy variable reflects whether the woodlot is village-managed or tabia-managed. Finally, the size of the woodlot is included to investigate whether there are economies (or diseconomies) of scale in woodlot protection and management.

We find that the intensity of management of woodlots (labor input, community contribution to protection, and planting density) is lowest in the Central zone of Tigray, while survival rate is the highest in this zone (controlling for other differences between zones). This suggests that a less intensive approach to woodlots is being pursued in the Central zone, but that this can be consistent with higher survival rates (though lower density of surviving trees), probably because of less competition among trees in the less densely planted woodlots for water, sunlight and nutrients. Community labor input is also lower in the Eastern zone than in the Southern zone, but community contributions to protecting woodlots are greater, leading to fewer violations of restrictions and higher survival rates. Thus, the approach to community woodlots in the Eastern zone appears to be oriented towards less labor intensity of management but greater effort to protect the trees, with favorable impact on tree survival. We find no statistically significant differences in tree management, protection or survival between the Western and Southern zones. 
We find that the labor intensity of woodlot management is positively associated with population density, but negatively associated with population density squared, consistent with the hypothesis of an inverse U-shaped relationship between population density and collective action. The turning point in this relationship (where maximum predicted collective labor input occurs) is at 191 persons per square $\mathrm{km}$., well within the range of population density observed in Tigray (the range in our sample is from 39 to 302 persons per square $\mathrm{km}$.). ${ }^{3}$ The magnitude of the impact is also substantial: an increase of population density from 40 to 50 persons per square $\mathrm{km}$. would increase predicted labor input per capita by 0.22 labor days per capita (more than the average labor input per capita on woodlots).

Other indicators of collective action and its effectiveness-including whether the community pays for a guard, violations of restrictions and survival rate of trees - also show a relationship consistent with the inverted-U hypothesis (with the signs of the coefficients reversed for violations of restrictions), though these relationships are statistically insignificant. Unexpectedly, there is a statistically significant U-shaped relationship between planting density and population density, with planting density first falling and later rising as population density increases (the turning point is at 180 persons per square $\mathrm{km}$.). It may be that lower planting density at moderate population density is a result of collective action; i.e., a decision by communities to not overexploit the woodlot area by restricting the planting density. If this is the case, then this relationship also supports the hypothesis of an inverse- $U$ relationship between collective action and population density.

\footnotetext{
${ }^{3}$ Summary statistics of the variables used in the regressions are presented in the Annex.
} 
However, this is only an ex post hypothesis to explain a result that we did not expect, and further research would be needed to confirm or reject this hypothesis.

With regard to market access, we find that communities that are more remote provide greater collective labor input, plant trees more densely, and obtain higher survival rates. These results are both statistically and quantitatively significant: being 10 $\mathrm{km}$. further from the woreda town increases predicted labor input by 0.06 labor days per capita (one-third of average labor input), predicted planting density by 2400 trees per ha. and tree survival by 3.5 percentage points. These findings are consistent with the argument that improved market access undermines collective action by increasing labor opportunity costs and/or giving people more exit options from the community.

The presence of external organizations, as indicated by whether the woodlot was promoted by an external organization (usually the BoANRD), has a negative association with whether the community pays for a guard and with tree survival. The negative association with community payment for a guard is probably due to the fact that external organizations often pay for the guard, as discussed earlier, reducing the need for this aspect of collective action. This is similar to results found by Pender and Scherr (1999) in Honduras, where external government organizations were found to displace local collective action. The negative association of external promotion with tree survival suggests that external programs may not be achieving full participation of local communities in promoting woodlots. Part of the problem may be that local communities often prefer to plant eucalyptus, which survive well and grow rapidly under the uncertainrainfall of Tigray, whereas external organizations sometimes promote other species that may be less hearty or less preferred by local households (Jagger and Pender, 2000). 
Contrary to our expectations, we did not find that collective action was significantly greater or more effective on village-managed woodlots than on tabia-managed woodlots, after controlling for other factors. This may be because the differences in benefits, community stability or cohesiveness between the tabia level and the village level are relatively small; while other factors such as population density, market access or external organizations may be more responsible for the differences in collective action found on different woodlots. The area of the woodlot also had a statistically insignificant impact on our measures of collective management of woodlots and its effectiveness. This suggests that economies or diseconomies of scale in woodlot management are weak.

A possible alternative explanation for the weak influence of some variables is that there may be multicollinearity among the explanatory variables. We tested for problems of multicollinearity, and found potential problems only between the population density and density- squared variables. The correlation between these variables is almost 0.98 , leading to high variance inflation factors for these variables (Chatterjee and Price, 1991). None of the other explanatory variables has a variance inflation factor greater than 3 , indicating that multicollinearity is not a major concern for these variables (Ibid.).

Because of the high correlation between population density and density-squared, we repeated the regressions in Table 4 excluding population density squared (Table 5). The results are generally very similar, with a few notable exceptions. Unlike in Table 4, we find that population density is negatively associated with the probability that a community will pay for a guard and with tree survival. These effects were masked by the multicollinearity, and suggest that population pressure tends to undermine collective action to a greater extent than was apparent in Table 4. We find that village-managed 
woodlots have higher survival rates than tabia-managed woodlots in Table 5, with the difference being marginally statistically significant (at the $10 \%$ level), and quantitatively large (10 percentage points). This effect was also apparently masked by multicollinearity in Table 4. Thus, we do have weak evidence supporting our hypothesis that collective action would be more effective on village-managed woodlots, controlling for other factors.

\section{CONCLUSION AND IMPLICATIONS}

Collective action in managing woodlots generally functions well in Tigray, which supports the role of community resource management in redressing resource degradation. Despite the fact that the communities received little benefits from woodlots by 1998 , the woodlots contribute substantially to community wealth, and community members are generally satisfied with the woodlots as a reserve of natural capital. Nevertheless, restrictions on the use of woodlots appear may be contributing to fuelwood shortages in the near term.

Benefits were greater and reported problems of managing the woodlots were less on woodlots managed at the village level than those managed at the higher tabia level. Communities that managed woodlots at the village level applied greater labor inputs, planted trees much more densely, more often hired a guard, and less often had violations of restrictions. Although average tree survival (per tree planted) was lower on villagemanaged woodlots, the number of trees surviving per ha. was greater in village woodlots. Most of these differences were not found to be statistically significant, however, when controlling for other factors, suggesting that other factors besides the level of management are more important in determining the extent and effectiveness of collective management of community woodlots. 
Table 5: Determinants of collective action and its effectiveness, excluding population density squared as an explanatory variable $^{\mathrm{a}}$

\begin{tabular}{|c|c|c|c|c|c|}
\hline Explanatory variable & $\begin{array}{l}\text { Collective labor input } \\
\text { (person-days per capita) }\end{array}$ & $\begin{array}{c}\text { Whether community } \\
\text { pays for guard }\end{array}$ & $\begin{array}{l}\text { Whether any violations } \\
\text { of restrictions occurred }\end{array}$ & $\begin{array}{l}\text { Number of trees } \\
\text { planted per hectare }\end{array}$ & $\begin{array}{l}\text { Survival rate of } \\
\text { planted trees }(\%)\end{array}$ \\
\hline $\begin{array}{l}\text { Central zone (cf. Southern } \\
\text { zone) }\end{array}$ & $-1.547 * * *$ & $-1.280^{*}$ & -0.374 & $-8406^{*}$ & $16.94 * * *$ \\
\hline $\begin{array}{l}\text { Eastern zone (cf. Southern } \\
\text { zone) }\end{array}$ & $-0.678 * *$ & $1.027^{*}$ & $-1.478 * * *$ & 3558 & $17.03 * *$ \\
\hline $\begin{array}{l}\text { Western zone (cf. Southern } \\
\text { zone) }\end{array}$ & -1.076 & 0.033 & -0.686 & 5268 & 5.82 \\
\hline $\begin{array}{l}1994 \text { population density (per } \\
\mathrm{km}^{2} \text { ) }\end{array}$ & $0.00408^{*}$ & $-0.00788 * *$ & 0.00157 & 21.6 & $-0.0910 * * *$ \\
\hline $\begin{array}{l}\text { Distance to woreda town } \\
(\mathrm{km} .)\end{array}$ & 0.00354 & -0.00791 & -0.00391 & $274.1 * *$ & $0.338 * * *$ \\
\hline $\begin{array}{l}\text { Woodlot promoted by } \\
\text { external organization }\end{array}$ & 0.3805 & $-1.392 * * *$ & 0.212 & 6107 & $-5.795 * * *$ \\
\hline $\begin{array}{l}\text { Woodlot managed by village } \\
\text { (cf. managed by tabia) }\end{array}$ & -00807 & 0.763 & -0.185 & -1770 & $10.24 *$ \\
\hline Area of woodlot (ha.) & -0.00631 & -0.0192 & 0.0113 & -242.9 & 0.413 \\
\hline Intercept & -0.7519 & $2.333 * *$ & -0.375 & -7592 & $46.18 * * *$ \\
\hline Type of regression & Tobit & Probit & Probit & Least squares & Tobit \\
\hline $\mathrm{R}^{2}$ (if applicable) & NA & NA & NA & 0.456 & $0.435^{\mathrm{c}}$ \\
\hline $\begin{array}{l}\text { Number of positive } \\
\text { observations/total obs. }\end{array}$ & $66 / 223$ & $110 / 219$ & $53 / 219$ & $76 / 76^{\mathrm{d}}$ & $73 / 76^{\mathrm{d}}$ \\
\hline
\end{tabular}


We found some support for the hypothesis of an inverted U-shaped relationship between population density and collective action, especially with respect to collective labor input. However, many of the findings with respect to population density were statistically weak, and some suggest that population pressure can undermine collective action (especially contribution to protection of woodlots) even at lower levels of population density.

We found that access to markets appears to undermine the intensity of collective management of woodlots and its effectiveness in ensuring tree survival, probably because this increases the opportunity costs of people's time and/or the "exit options" of community members. Promotion of woodlots by external organizations appears to displace local collective action in protecting the woodlot and contributes to lower tree survival rates.

Our findings imply that collective action can be an effective means of redressing resource degradation and increasing community wealth. However, they also suggest that the effectiveness of collective action may be undermined by restrictions that limit the benefits of woodlots to local communities, by promotional efforts that displace local initiative or promote planting of trees that are less acceptable to local communities, or by management at a higher administrative level. Community management of woodlots, and perhaps other natural resources, is likely to be more effective if conducted at the lowest level consistent with concerns about distributional issues and externalities, and if external interventions respond to local concerns and priorities rather than being imposed. 
Our findings suggest that collective woodlot management is likely to be more intensive and effective in communities that are more remote from markets or that have low to moderate population density. In such communities, which are often in lower potential areas where agricultural development is difficult to achieve, development and management of community woodlots may be a key element of an effective development strategy. In areas of greater market access or high population density, private-oriented approaches to resource management may be more effective. 


\section{ACKNOWLEDGMENTS}

We gratefully acknowledge the financial support of the Swiss Agency for Development and Cooperation. We also thank Mekelle University College for institutional support during the field work, and the Tigray Regional Bureau of Agriculture and Natural Resource Development and the Tigray Regional Bureau of Planning and Economic Development for logistical support and collaboration in the work. We are especially grateful to the many officials and farmers who patiently responded to our many questions. The usual disclaimer applies. 
Annex: Summary statistics of variables used in regressions

\begin{tabular}{|c|c|c|c|c|c|}
\hline Variable & $\begin{array}{c}\text { No. of } \\
\text { observations }\end{array}$ & Mean $^{\mathrm{a}}$ & $\begin{array}{c}\text { Standard } \\
\text { Error }^{\mathrm{a}}\end{array}$ & Minimum & Maximum \\
\hline $\begin{array}{l}\text { Labor days per } \\
\text { capita }\end{array}$ & 233 & 0.165 & 0.045 & 0 & 4.08 \\
\hline $\begin{array}{l}\text { Whether community } \\
\text { hires a guard }\end{array}$ & 223 & 0.490 & 0.092 & 0 & 1 \\
\hline $\begin{array}{l}\text { Whether violations } \\
\text { of restrictions } \\
\text { occurred }\end{array}$ & 223 & 0.228 & .054 & 0 & 1 \\
\hline $\begin{array}{l}\text { Number of trees } \\
\text { planted per ha. }\end{array}$ & 80 & 4453 & 1837 & 333 & 51750 \\
\hline $\begin{array}{l}\text { Tree survival rate } \\
(\%)\end{array}$ & 80 & 63.7 & 5.1 & 0 & 97.5 \\
\hline Southern zone & 233 & 0.141 & 0.049 & 0 & 1 \\
\hline Central zone & 233 & 0.423 & 0.100 & 0 & 1 \\
\hline Eastern zone & 233 & 0.397 & 0.100 & 0 & 1 \\
\hline Western zone & 233 & 0.039 & 0.019 & 0 & 1 \\
\hline $\begin{array}{l}1994 \text { population } \\
\text { density (per km. }{ }^{2} \text { ) }\end{array}$ & 225 & 154.9 & 14.7 & 39.5 & 301.7 \\
\hline $\begin{array}{l}\text { Distance to woreda } \\
\text { town }(\mathrm{km} .)\end{array}$ & 229 & 27.6 & 5.0 & 0 & 87 \\
\hline $\begin{array}{l}\text { Woodlot promoted } \\
\text { by external } \\
\text { organization }\end{array}$ & 227 & 0.949 & 0.233 & 0 & 1 \\
\hline $\begin{array}{l}\text { Woodlot managed } \\
\text { by village (cf. } \\
\text { managed by tabia) }\end{array}$ & 227 & 0.799 & 0.063 & 0 & 1 \\
\hline $\begin{array}{l}\text { Area of woodlot } \\
\text { (ha.) }\end{array}$ & 227 & 7.76 & 1.34 & 0.13 & 100 \\
\hline
\end{tabular}

\footnotetext{
${ }^{a}$ Means and standard errors are corrected for sampling stratification and weights.
} 


\section{REFERENCES}

Baland, J.-M., and J.-P. Platteau. 1996. Halting degradation of natural resources: Is there a role for rural communities? Oxford: Clarendon Press.

Boserup, E. 1965. The conditions of agricultural growth. New York: Aldine Publishing Co.

Bureau of Agriculture and Natural Resource Development (BoANRD). 1996. Tigray forestry action program, 1. Mekelle.

1995. Agriculture in Tigray. Paper presented at Symposium on Agricultural development in Humera Area of Tigray. Mekelle.

Chatterjee, S., B. Price. 1991. Regression analysis by example, $2^{\text {nd }}$ ed. New York: John Wiley \& Sons.

Gebremedhin, B. 1998. The economics of soil conservation investments in the Tigray Region of Ethiopia. Ph D diss. Department of Agricultural Economics: Michigan State University.

Gordon, H.S. 1954. The economic theory of a common property resource: The fishery. Journal of Political Economy 62(2): 124-142.

Hagos, F., J. Pender, and N. Gebresselassie. 1999. Land degradation in the highlands of Tigray and strategies for sustainable land management. Socio-economics and Policy Research Working Paper No. 25. International Livestock Research Institute. 
Hayami, Y. and V. Ruttan. 1985. Agricultural development: An international perspective, $2^{\text {nd }}$ ed. Baltimore: Johns Hopkins University Press.

Hoben, A. 1995. Paradigms and politics: The cultural construction of environmental policy in Ethiopia. World Development 23(6): 1007-1021.

Hurni, H. 1985. Erosion-productivity-conservation systems in Ethiopia. Paper presented at the $4^{\text {th }}$ International Conference on Soil Conservation, Venezuela.

Jagger, P. and J. Pender. 2000. The role of trees in sustainable development of less-favored lands: The case of eucalyptus in Ethiopia. Mimeo. Washington, D.C.: Environment and Production Technology Division, International Food Policy Research Institute.

North, D. 1990. Institutions, institutional change and economic performance. Cambridge: Cambridge University Press.

Olson, M. 1965. The logic of collective action. Public goods and the theory of groups. Cambridge: Harvard University Press.

Otsuka, K. and F. Place, eds. 1999. Land tenure and natural resource management: Forest, agroforest and cropland management in Asia and Africa. Book manuscript. Washington, D.C.: International Food Policy Research Institute.

Pender, J. 1999. Rural population growth, agricultural change and natural resource management in developing countries: A review of hypotheses and some evidence 
from Honduras. Environment and Production Division Discussion Paper No. 48. Washington D.C.: International Food Policy Research Institute.

Pender, J. and S. Scherr. 1999. Organizational development and natural resource management: Evidence from Central Honduras. Environment and Production Division Discussion Paper No. 49. Washington D.C.: International Food Policy Research Institute.

Rasmussen, L.N., and R. Meinzen-Dick. 1995. Local organizations for natural resource management: Lessons from theoretical and empirical literature. Environment and Production Technology Division Discussion Paper No. 11. Washington D.C.: International Food Policy Research Institute.

Swallow, B.M. and D.W. Bromley. 1995. Institutions, governance and incentives in common property regimes for African rangelands. Environment and Resource Economics 6: 99-118.

Turner, R.K., D. Pearce, and I. Bateman. 1994. Environmental economics: An introduction. Hertfordshire: Harvester WheatSheaf.

Virgo, K.J. and R.N. Munro. 1978. Soil and erosion features of the central plateau of Tigray. Geoderma 20(1978): 131-157.

Warren, A. and M. Khogali. 1992. Assessment of desertification and drought in the Sudano-Sahelian Region, 1985-1991. New York: UNSO. 
Wolde-Giorgis, T. 1993. Survival strategies and coping mechanisms of peasants to famine: The case of Tigray, Ethiopia. PhD diss. University of Denver: Faculty of the Graduate School of International Studies. 


\section{List of EPTD Discussion Papers}

01 Sustainable Agricultural Development Strategies in Fragile Lands, by Sara J. Scherr and Peter B.R. Hazell, June 1994.

02 Confronting the Environmental Consequences of the Green Revolution in Asia, by Prabhu L. Pingali and Mark W. Rosegrant, August 1994.

03 Infrastructure and Technology Constraints to Agricultural Development in the Humid and Subhumid Tropics of Africa, by Dunstan S.C. Spencer, August 1994.

04 Water Markets in Pakistan: Participation and Productivity, by Ruth MeinzenDick and Martha Sullins, September 1994.

05 The Impact of Technical Change in Agriculture on Human Fertility: District-level Evidence from India, by Stephen A. Vosti, Julie Witcover, and Michael Lipton, October 1994.

06 Reforming Water Allocation Policy Through Markets in Tradable Water Rights: Lessons from Chile, Mexico, and California, by Mark W. Rosegrant and Renato Gazmuri S., October 1994.

07 Total Factor Productivity and Sources of Long-Term Growth in Indian Agriculture, by Mark W. Rosegrant and Robert E. Evenson, April 1995.

08 Farm-Nonfarm Growth Linkages in Zambia, by Peter B.R. Hazell and Behjat Hojjati, April 1995.

09 Livestock and Deforestation in Central America in the 1980s and 1990s: A Policy Perspective, by David Kaimowitz (Interamerican Institute for Cooperation on Agriculture), June 1995.

10 Effects of the Structural Adjustment Program on Agricultural Production and Resource Use in Egypt, by Peter B. R. Hazell, Nicostrato Perez, Gamal Siam and Ibrahim Soliman, August 1995. 
11 Local Organizations for Natural Resource Management: Lessons from Theoretical and Empirical Literature, by Lise Nordvig Rasmussen and Ruth Meinzen-Dick, August 1995.

12 Quality-Equivalent and Cost-Adjusted Measurement of International Competitiveness in Japanese Rice Markets, by Shoichi Ito, Mark W. Rosegrant, and Mercedita C. Agcaoili-Sombilla, August, 1995.

13 Role of Inputs, Institutions, and Technical Innovations in Stimulating Growth in Chinese Agriculture, by Shenggen Fan and Philip G. Pardey, September 1995.

14 Investments in African Agricultural Research, by Philip G. Pardey, Johannes Roseboom, and Nienke Beintema, October 1995.

15 Role of Terms of Trade in Indian Agricultural Growth: A National and State Level Analysis, by Peter B. R. Hazell, V. N. Misra and Behjat Hojjati, December 1995.

16 Policies and Markets for Non-Timber Tree Products, by Peter A. Dewees and Sara J. Scherr, March 1996.

17 Determinants of Farmers' Indigenous Soil and Water Conservation Investments in India's Semi-Arid Tropics, by John Pender and John Kerr, August 1996.

18 Summary of a Productive Partnership: The Benefits from U.S. Participation in the CGIAR, by Philip G. Pardey, Julian M. Alston, Jason E. Christian and Shenggen Fan, October 1996.

19 Crop Genetic Resource Policy: Towards a Research Agenda, by Brian D. Wright, October 1996.

20 Sustainable Development of Rainfed Agriculture in India, by John M. Kerr, November 1996.

21 Impact of Market and Population Pressure on Production, Incomes and Natural Resources in the Dryland Savannas of West Africa: Bioeconomic Modeling at the Village Level, by Bruno Barbier, November 1996. 
22 Why Do Projections on China's Future Food Supply and Demand Differ? by Shenggen Fan and Mercedita Agcaoili-Sombilla, March 1997.

23 Agroecological Aspects of Evaluating Agricultural $R \& D$, by Stanley Wood and Philip G. Pardey, March 1997.

24 Population Pressure, Land Tenure, and Tree Resource Management in Uganda, by Frank Place and Keijiro Otsuka, March 1997.

25 Should India Invest More in Less-favored Areas? by Shenggen Fan and Peter Hazell, April 1997.

26 Population Pressure and the Microeconomy of Land Management in Hills and Mountains of Developing Countries, by Scott R. Templeton and Sara J. Scherr, April 1997.

27 Population Land Tenure, and Natural Resource Management: The Case of Customary Land Area in Malawi, by Frank Place and Keijiro Otsuka, April 1997.

28 Water Resources Development in Africa: A Review and Synthesis of Issues, Potentials, and Strategies for the Future, by Mark W. Rosegrant and Nicostrato D. Perez, September 1997.

29 Financing Agricultural R\&D in Rich Countries: What's Happening and Why, by Julian M. Alston, Philip G. Pardey, and Vincent H. Smith, September 1997.

30 How Fast Have China's Agricultural Production and Productivity Really Been Growing? by Shenggen Fan, September 1997.

31 Does Land Tenure Insecurity Discourage Tree Planting? Evolution of Customary Land Tenure and Agroforestry Management in Sumatra, by Keijiro Otsuka, S. Suyanto, and Thomas P. Tomich, December 1997.

32 Natural Resource Management in the Hillsides of Honduras: Bioeconomic Modeling at the Micro-Watershed Level, by Bruno Barbier and Gilles Bergeron, January 1998. 
33 Government Spending, Growth and Poverty: An Analysis of Interlinkages in Rural India, by Shenggen Fan, Peter Hazell, and Sukhadeo Thorat, March 1998, Revised December 1998.

34 Coalitions and the Organization of Multiple-Stakeholder Action: A Case Study of Agricultural Research and Extension in Rajasthan, India, by Ruth Alsop, April 1998.

35 Dynamics in the Creation and Depreciation of Knowledge and the Returns to Research, by Julian Alston, Barbara Craig, and Philip Pardey, July 1998.

36 Educating Agricultural Researchers: A Review of the Role of African Universities, by Nienke M. Beintema, Philip G. Pardey, and Johannes Roseboom, August 1998.

37 The Changing Organizational Basis of African Agricultural Research, by Johannes Roseboom, Philip G. Pardey, and Nienke M. Beintema, November 1998.

38 Research Returns Redux: A Meta-Analysis of the Returns to Agricultural R\&D, by Julian M. Alston, Michele C. Marra, Philip G. Pardey, and T.J. Wyatt, November 1998.

39 Technological Change, Technical and Allocative Efficiency in Chinese Agriculture: The Case of Rice Production in Jiangsu, by Shenggen Fan, January 1999.

40 The Substance of Interaction: Design and Policy Implications of NGOGovernment Projects in India, by Ruth Alsop with Ved Arya, January 1999.

41 Strategies for Sustainable Agricultural Development in the East African Highlands, by John Pender, Frank Place, and Simeon Ehui, April 1999.

42 Cost Aspects of African Agricultural Research, by Philip G. Pardey, Johannes Roseboom, Nienke M. Beintema, and Connie Chan-Kang, April 1999. 
43 Are Returns to Public Investment Lower in Less-favored Rural Areas? An Empirical Analysis of India, by Shenggen Fan and Peter Hazell, May 1999.

$44 \quad$ Spatial Aspects of the Design and Targeting of Agricultural Development Strategies, by Stanley Wood, Kate Sebastian, Freddy Nachtergaele, Daniel Nielsen, and Aiguo Dai, May 1999.

45 Pathways of Development in the Hillsides of Honduras: Causes and Implications for Agricultural Production, Poverty, and Sustainable Resource Use, by John Pender, Sara J. Scherr, and Guadalupe Durón, May 1999.

46 Determinants of Land Use Change: Evidence from a Community Study in Honduras, by Gilles Bergeron and John Pender, July 1999.

47 Impact on Food Security and Rural Development of Reallocating Water from Agriculture, by Mark W. Rosegrant and Claudia Ringler, August 1999.

48 Rural Population Growth, Agricultural Change and Natural Resource Management in Developing Countries: A review of Hypotheses and Some Evidence from Honduras, by John Pender, August 1999.

49 Organizational Development and Natural Resource Management: Evidence from Central Honduras, by John Pender and Sara J. Scherr, November 1999.

50 Estimating Crop-Specific Production Technologies in Chinese Agriculture: A Generalized Maximum Entropy Approach, by Xiaobo Zhang and Shenggen Fan, September 1999.

51 Dynamic Implications of Patenting for Crop Genetic Resources, by Bonwoo Koo and Brian D. Wright, October 1999.

52 Costing the Ex Situ Conservation of Genetic Resources: Maize and Wheat at CIMMYT, by Philip G. Pardey, Bonwoo Koo, Brian D. Wright, M.Eric van Dusen, Bent Skovmand, and Suketoshi Taba, October 1999.

53 Past and Future Sources of Growth for China, by Shenggen Fan, Xiaobo Zhang, and Sherman Robinson, October 1999. 
$54 \quad$ The Timing of Evaluation of Genebank Accessions and the Effects of Biotechnology, by Bonwoo Koo and Brian D. Wright, October 1999.

55 New Approaches to Crop Yield Insurance in Developing Countries, by Jerry Skees, Peter Hazell, and Mario Miranda, November 1999.

56 Impact of Agricultural Research on Poverty Alleviation: Conceptual Framework with Illustrations from the Literature, John Kerr and Shashi Kolavalli, December 1999.

57 Could Futures Markets Help Growers Better Manage Coffee Price Risks in Costa Rica? by Peter Hazell, January 2000.

58 Industrialization, Urbanization, and Land Use in China, by Xiaobo Zhang, Tim Mount and Richard Boisvert, January 2000.

$59 \quad$ Water Rights and Multiple Water Uses: Framework and Application to Kirindi Oya Irrigation System, Sri Lanka, by Ruth Meinzen-Dick and Margaretha Bakker, March 2000.

60 Community Natural Resource Management: The Case of Woodlots in Northern Ethiopia, Berhanu Gebremedhin, by John Pender and Girmay Tesfaye, April 2000. 